\title{
BIOPOLITICS AND HOMO SACER IN A TORTURE CENTER IN CHILE*
}

\begin{abstract}
THIS ARTICLE EXPLAINS HOW THE CONCEPTS OF BIOPOLITICS AND HOMO SACER CONTRIBUTE TO THE UNDERSTANDING OF WHAT HAPPENED IN THE VILLA GRIMALDI CONCENTRATION CAMP AND TORTURE CENTER DURING THE DICTATORSHIP OF GENERAL AUgUSTO Pinochet, IN ChILE. Prisoners Were humiliated AND TORTURED, LOSING THEIR CONDITION AS SUBJECTS OF LAW. THE REIFICATION PROCESS OF THE PRISONERS BY SADIST GUARDS AND AGENTS WAS ADDED TO THE IMPOSSIBILITY OF THE VICTIMS TO LEGALLY DEFEND THEMSELVES IN FRONT OF TRIBUNALS. THE ARCHAIC ROMAN LAW FIGURE OF HOMO SACER IS PERFECTLY APPLICABLE TO EXPLAIN THE SITUATION OF THE PERSONS KEPT IN CLANDESTINE CONCENTRATION CAMPS AS VILLA GRIMALDI. THE NOTION OF SUPERSTES TORMENTORUM (SURVIVOR OF TORTURES) IS ALSO PRESENTED HERE FOR FURTHER DISCUSSION IN ORDER TO REFER TO THE COMPLEX AND OFTEN PAINFUL PROCESS IN WHICH THE 'VICTIMS-SURVIVORS-WITNESSES' OF THE HORROR OF VILLA GRIMALDI AND OTHER SIMILAR SPACES TRY TO REINSERT IN SOCIETY.
\end{abstract}

\section{KEYWORDS}

BIOPOLITICS; HOMO SACER; TORTURE; MILITARY DICTATORSHIP; VILLA GRIMALDI.

\author{
Hugo Rojas Corral
}

BIOPOLÍTICA E HOMO SACER EM UM CENTRO DE TORTURA

NO CHILE

\section{RESUMO}

ESTE ARTIGO EXPLICA COMO OS CONCEITOS DE BIOPOLITICA E HOMO SACER CONTRIBUEM PARA A COMPREENSÃO DO QUE ACONTECEU NO CAMPO DE CONCENTRAÇÃO E CENTRO DE TORTURA VILLA GRIMALDI, DURANTE A DITADURA DO general Augusto Pinochet, no Chile. Os presos ERAM HUMILHADOS E TORTURADOS, PERDENDO SUA CONDICAAOO DE SUJEITOS DE DIREITO. O PROCESSO DE REIFICAÇÃO DOS PRISIONEIROS REALIZADO PELOS GUARDAS E AGENTES SÁDICOS SOMOU-SE À IMPOSSIBILIDADE DE AS VITTIMAS SE DEFENDEREM LEGALMENTE DIANTE DOS TRIBUNAIS. A FIGURA ARCAICA ROMANA DO HOMO SACER É PERFEITAMENTE APLICÁVEL PARA EXPLICAR A SITUAÇÃO DAS PESSOAS MANTIDAS EM CAMPOS DE CONCENTRAÇÃO CLANDESTINOS COMO VILLA GRIMALDI. A NOÇÃO DE SUPERSTES TORMENTORUM (SOBREVIVENTE DA TORTURA) É TAMBÉM APRESENTADA AQUI PARA UMA DISCUSSÃO MAIS APROFUNDADA, A FIM DE SE REFERIR AO PROCESSO COMPLEXO E DOLOROSO EM QUE AS "TESTEMUNHASVÍTIMAS-SOBREVIVENTES" DO HORROR DA VILLA GRIMALDI E OUTROS ESPAÇOS SIMILARES TENTAM SE REINSERIR NA SOCIEDADE.

\section{PALAVRAS-CHAVE}

BIOPOLITICA; HOMO SACER; TORTURA; DITADURA MILITAR; VILLA GRIMALDI. 


\section{INTRODUCTION}

The main purpose of this article is to explain how the philosophical notions of biopolitics, presented by Michel Foucault (1926-1984) ${ }^{1}$ and, homo sacer, reformulated by Giorgio Agamben (1942-), ${ }^{2}$ are applicable to what happened at Terranova concentration camp in Chile. This clandestine detention, interrogation, torture, and even execution center better known as Villa Grimaldi was managed by the National Intelligence Directorate (DINA) between 1974 and 1977 and then, by the National Information Center (CNI) between 1977 and 1989. Although the military dictatorship headed by General Augusto Pinochet lasted 17 years from the coup d'état from September $11^{\text {th }}$ 1973 to March $11^{\text {th }} 1990$, this research only concentrates in the period that DINA managed Villa Grimaldi as a headquarter of the Metropolitan Brigade and concentration camp. It is considered that between 4,500 and 5,000 left-wing supporters were detained in that place, most of them were tortured and, 226 of them were executed or are still disappeared.

The first part of this essay, in order to approach the investigated phenomenon, explains the notions of biopolitics and homo sacer under a theoretical framework. One of the intentions of Foucault's engaging project was to elaborate a novel theory of power that could explain the praxis of domination and power in different scenarios, such as family, education, work, etc. Foucault verifies that starting in the $18^{\text {th }}$ century, biological life enters the field of political techniques or rather, the biological field begins to be reflected in the political one. In the last part of the first volume of The History of Sexuality (1976), Foucault refers to biopolitics, showing how in modern life, devices of power are directly connected to the body (FOUCAULT, 1978 [1976], p. 184; GENEL, 2006, p. 43-62). Agamben problematized furthermore and complemented the concept of biopolitics with the notions of homo sacer (sacred man), concentration camp, and witness, with a new approach to sovereignty, and state of exception. He considers the camp as "the hidden matrix and nomos of the political space" (AGAMBEN, 2010 [1996], p. 37) or "the place in which the most absolute conditio inhumana ever to appear on Earth was realized" and, "the most absolute biopolitical space that has ever been realized" (AGAMBEN, 1998 [1995], p. 166 and p. 168-169; CASTRO, 2008, p. 49-85). In the second part, a brief historical explanation about DINA and Villa Grimaldi is presented in order to contextualize the case study to a broader audience. The third part aims at assembling the theoretical framework with the case study. In this section, it is explained why Villa Grimaldi can be characterized as a place created during a state of constitutional exception, where the prisoners lost their condition of legal subjects and were reified by the agents of DINA. As it will be shown, the control of the state was absolute regarding the bodies of the prisoners, violating their fundamental rights and impeding them to receive a proper defense in court. Finally, the most significant conclusions of this permanent and on-going research project on human rights are highlighted. 
From a methodological point of view, after revising the specialized literature, secondary sources and different testimonies of survivors of Villa Grimaldi, field work was conducted in Chile during August 2011. The visits to the Villa Grimaldi Peace Park including its Oral Archive ${ }^{3}$ the Museum of the Memory and Human Rights 4 and, the Vicarage of Solidarity Archives ${ }^{5}$ allowed me to confirm or correct the preliminary drafts of this document. I want to thank the recommendations of Pedro A. Matta, a law student at University of Chile at the time of his arrest, on May 1975 and prisoner during thirteen months in different camps/centers, including Villa Grimaldi and the suggestions made by Elizabeth Lira, Commissioner of the National Commission on Torture and Political Imprisonment (Valech Commission, 2003-04) and Commissioner of the Presidential Advising Commission for the Qualification of Disappeared Detainees, Executed Prisoners, and Victims of Torture and Political Imprisonment (Valech Commission II, 2010-11). ${ }^{6}$

\section{Biopolitics AND HOMO SACER}

\section{I The nOtions of POWer ANd biopolitics in Michel Foucault}

Foucault challenged the way political power was understood and analyzed by classical authors as Jean Bodin, Thomas Hobbes, Montesquieu and even Karl Marx. In Discipline and Punish: The Birth of the Prison (1975), Foucault outlined that one of the central elements that characterizes modern society is the emergence of multiple disciplinary and surveillance techniques dedicated to control the mind and the body of the individuals in institutions like schools, hospitals, prisons, military bases and barracks, factories, etc. The fact that modern society is conceived by Foucault, like a 'disciplinary society', implies the recognition of the notable power that a set of technical and disciplinary procedures has reached since the $18^{\text {th }}$ century. The main goal of those procedures has been to control the minds and bodies of the individuals and to make them, every day, more docile and able of manipulation (FOUCAULT, 1987 [1975], esp. p. 199-230; HEFFES, Dec. 2006 - Mar. 2007, p. 1-22). Although, the exercise of power is diffused in various institutions and social interactions, some more visible than others e.g. in daily life, work routine, etc., which allows Foucault to introduce the notion of 'micro-physics' of power (VÁSQUEZ, 2009, p. 72), it is unquestionable that the modern state continues to be the most relevant agent in the anatomo-politics of human body. Power is omnipresent in all social interactions and relations, and in many times the agent that exercises power is invisible, while the subordinate is always visible. The best example of this new form to conceive modern disciplinary power is the Panopticon, proposed by Jeremy Bentham in 1787 to improve the efficiency of the penitentiary system in England (BENTHAM, 1995 [1791], p. 29-95). Prisons and concentration camps can be, in part, understood as 
extreme spaces of disciplinary control of the prisoners' bodies. Also, the camps can be seen as the climax of rational and technological calculated oppression, in the service of the interests of someone who exercises power. ${ }^{7}$

Also, in the last chapter of the first volume of The History of Sexuality, Foucault begins a reflection on how since the $18^{\text {th }}$ century politics and in particular the state has penetrated in the biological life of the citizens (FOUCAULT, 1978 [1976], p. 163-169). The state power has entered into demographic aspects and concerns, regulating aspects of life like births and abortions, health and illnesses, the mobility of people, death, races, etc. (FOUCAULT, 2010 [2004], p. 359). What Foucault notices is that the field of interest or the center of gravity of politics has changed in comparison with the previous centuries and, it is perfectly possible, and even preferable, to understand politics as 'biopolitics'. If, since the $18^{\text {th }}$ century, a fundamental change has taken place in politics when the biological dimension of people's lives became controlled by the state, then the relationship between the exercise of power by the authority and the right of life and death of the citizens had to be different (FOUCAULT, 2003 [1997], p. 240). For example, if sovereign power in the past was characterized by the capacity of taking life or letting live, in the last centuries in contrast, the sovereign also has the power to 'make live and let die' (FOUCAULT, 2003 [1997], p. 241). Additionally, biopolitics cannot be conceived in individual terms like disciplinary devices, but in a global mass macro-level: "Biopolitics deals with population, with the population as a political problem, as a problem that is at once scientific and political, as a biological problem and as power's problem" (FOUCAULT, 2003 [1997], p. 245). The exercise of biopolitics implies more risks for mankind than disciplinary power, precisely for being the state the main institution that can completely regulate and control the life of the population.

Consequently, the fusion of disciplinary techniques with state regulations of life and death, forces us to understand how power has been exercised in modern society in a very different way compared to previous historical stages. When biopower and disciplinary devices are applied by a totalitarian regime, dictatorship, or liberal democracy in a state of constitutional exception, then the consequences in the lives of citizens can be horrible, as we have seen in the $20^{\text {th }}$ century. A central aspect in this debate and new perception of political power has to do with the foundations of biopolitics. I disagree with Foucault when he affirms that "once the State functions in the biopower mode, racism alone can justify the murderous function of the State" (FOUCAULT, 2003 [1997], p. 256), because ideologies can also be seen as a central element that can define the regulation of the population, as it happened in Pinochet's dictatorship.

\section{I.2 The notion of homo sacer in Giorgio Agamben}

When meditating on the relationship between politics and life, Agamben dismantles the traditional definition of sovereignty given by German jurist Carl Schmitt: "Sovereign is 
who decides on the exception" (SCHMITT, 1965 [1922]), p. 5). The sovereign can determine the suspension of certain rules and, in particular norms that recognize fundamental rights so, they are not effective during a period of time while the authority is able to put an end to an emergency, conflict, war, etc. ${ }^{8}$ In such a sense, the state of constitutional exception is a kind of no man's land between public law and political facts (AGAMBEN, 2010 [2003], p. 10), where the legal order is redefined (AGAMBEN, 2010 [1999], p. 49). When the political authority establishes the state of exception, risks like the implementation of concentration camps in the country appear, and also transitory measures with time can become the general rule. For example, "Auschwitz is indeed the place where the state of exception coincides perfectly with the rule and, an extreme situation becomes the paradigm itself of the day to day" (AGAMBEN, 2010 [1999], p. 50).

In the archaic Roman law, the enigmatic notion of the homo sacer (sacred man, bare life, $z o \bar{e}$ ) refers to the person who was condemned to live outside the city for having committed serious offenses. An offender that received the condition of homo sacer lost all social and legal relevance:

Homo Sacer is a juridical term from archaic Roman law designating an individual who, in response to a grave trespass, is casted out of the city. From the moment of his ritual pronouncement as homo sacer, he can be killed with impunity by anyone but cannot be employed in sacrificial rituals that require the taking of a life. This "sacred man" is thereby removed from the continuum of social activity and communal legislation; the only law that still applies to him is the one that irrevocably casts him out of the communal sphere (DURANTAYE, 2009, p. 206). ${ }^{9}$

From the moment the individual was named homo sacer, anyone who killed such individual would be deemed to have committed homicide and the body could not be offered as sacrifice (sacrificium) to the gods of Rome (AGAMBEN, 1998 [1995], p. 8). ${ }^{10}$ To explain the situation in which the prisoners of the concentration camps of the Nazi régime were, Agamben resurrects and appeals to the figure of the homo sacer. Once the individual was arrested and entered the camp, he/she did not have any possibility to defend him/herself and, if somebody killed him/her, no crime was committed by the perpetrator. The camp "is a portion of the territory that is placed outside the normal juridical order but, not because of that it is simply an external space" (AGAMBEN, 2010 [1996], p. 39). The problem is that in the camp the biological and political become indistinguishable between each other (AGAMBEN, 2010 [1996], p. 115 $)^{11}$ and, whether we want it or not, maybe that is the biggest complexity that modern life must face and assume. 
Inasmuch as its inhabitants have been stripped of any political status and reduced completely to naked life, the camp is also the most biopolitical space that has ever been realized - a space where power confronts nothing other than pure biological life without any mediation. The camp is the paradigm itself of political space at the point in which politics become biopolitics and the homo sacer becomes undistinguishable from the citizen (AGAMBEN, 2000, p. 40).

\section{DiNA AND Villa Grimaldi}

DINA was the secret police of the Military Junta during the first four years of the dictatorship although, in reality, they responded directly to General Pinochet. Its purpose was to carry intelligence work in order to disarticulate the leaders and intellectuals of the left-wing Unidad Popular. Besides the intelligence tasks and maintaining Pinochet informed about the situation in the country, it was an organism that assumed repressive functions as well. Among the operations carried out by its agents were housebreakings, detentions, kidnappings, interrogations and executions of 'internal enemies' during the periods of constitutional exception. Its legal existence is dated to June $1974,{ }^{12}$ but the fact is that it began operating at the end of 1973 . In charge of DINA was lieutenant colonel Manuel Contreras, who in 1967 was trained in a military intelligence unit at Fort Benning, United States (ENSALACO, 2002, p. 105) and later reached the rank of general. Contreras had relationships with the CIA and, even received money in exchange of information. ${ }^{13}$ His office was in downtown Santiago but he regularly visited the different detention and concentration camps Villa Grimaldi (Terranova Barracks), 38 London St. (Yucatan Barracks), 1367 José Domingo Cañas St. (Ollagüe Barracks), Venda Sexy or Discothèque (3037 Iran St.), 8630 Simón Bolívar Ave., etc. and was daily informed by his subordinate officers. In the last two decades, Contreras has been convicted in several cases of assassination, kidnapping, and forced disappearance of prisoners, and is currently serving sentences in Punta Peuco prison, near Santiago.

DINA operated outside the law. It is considered that it had 4,000 agents (50\% civilians and 50\% members of the armed forces) and at least 16,000 informants (TOLEDO et al., 2009, p. 66). The chiefs of DINA were trained in the School of the Americas in Panama, where they learned torture techniques and political repression. To justify their acts the officers invoked the National Security Doctrine and alluded to an 'internal civil war' in the country. The secret mission of DINA was to arrest and murder the leaders of the Marxist and revolutionary parties and movements: Communist Party (PC), Socialist Party (PS), Revolutionary Left Movement (MIR), United Popular Action Movement (MAPU) and, Christian Left (IC). It is necessary to mention that this 'internal war' never existed because, the left-wing sectors did not have any possibility neither to impede nor to revert the coup d'état or the dictatorship. 
At the beginning of the dictatorship the repression of DINA was massive but from 1974 it focused on the capture of the leaders of the parties of the Unidad Popular and MIR. In that sense, in 1974 DINA strongly repressed MIR, until disarticulating it, in 1975 the PS, and in 1976 the PC (POLICZER, 2009, p. 83). The autonomy and power that gradually DINA was acquiring besides the questioning for the systematic violations to the human rights that its agents made mainly in Chile although also abroad $^{14}$, generated nuisances in some high officers of the armed forces. Pinochet used DINA to impose and consolidate his power (POLICZER, 2009, p. 69-71), although internal and foreign pressures persuaded him to dissolve it in 1977. But, he substituted with another repressive organism: the National Information Center (CNI). ${ }^{15}$

DINA's main and more symbolic operations center was Villa Grimaldi, a 12,000 square meters property (TOLEDO et al., 2009, p. 123), located at 8200 José Arrieta Ave., Peñalolén, in Santiago's south-east, near the Andes Mountains. It is interesting to see the historical evolution of the property of the place because it exemplifies great part of the history of Chile: since time immemorial the property belonged to the Picunche indigenous communities; during the Spanish Colony the Hacienda Peñalolén was given to the Society of Jesus (expelled in 1767 and, its lands were distributed among influential Creoles); in the $19^{\text {th }}$ century it was in the hands of Juan Egaña, an intellectual and liberal politician and, later his family sold it to José Arrieta, a wealthy man. The mansion of the hacienda is today a private university, while the large house was acquired in 1964 by Emilio Vasallo Rojas who conditioned it as Restaurant Villa Grimaldi Paradise, in honor to his father, Emilio Vasallo Grimaldi. ${ }^{16}$ On September $12^{\text {th }} 1973$, one day after the coup, the large house was searched and later Vasallo was forced to sell the place to the Housing and Urbanism Service (SERVIU). On December 1973, it was transformed into a secret detention center and concentration camp for political repression. Once DINA was dissolved, it was used as administrative offices and, on August $7^{\text {th }}, 1980$ the property was bought by CNI. In 1987, it was illegally registered under General Hugo Salas Wenzel's name, director of CNI at the time, who transferred the property to EGPT Ltd., a construction company owned by his relatives that destroyed the place with bulldozers in 1989. Once democracy was recovered, the local movement Permanent Assembly for Human Rights promoted the state expropriation of the place. In 1996, the Villa Grimaldi Peace Park Corporation was established and one year later, the park was inaugurated, where a memorial was built and, in 2004, Villa Grimaldi Peace Park was declared national historical monument. ${ }^{17}$ 
figure 1 - RePlica of Villa Grimaldi

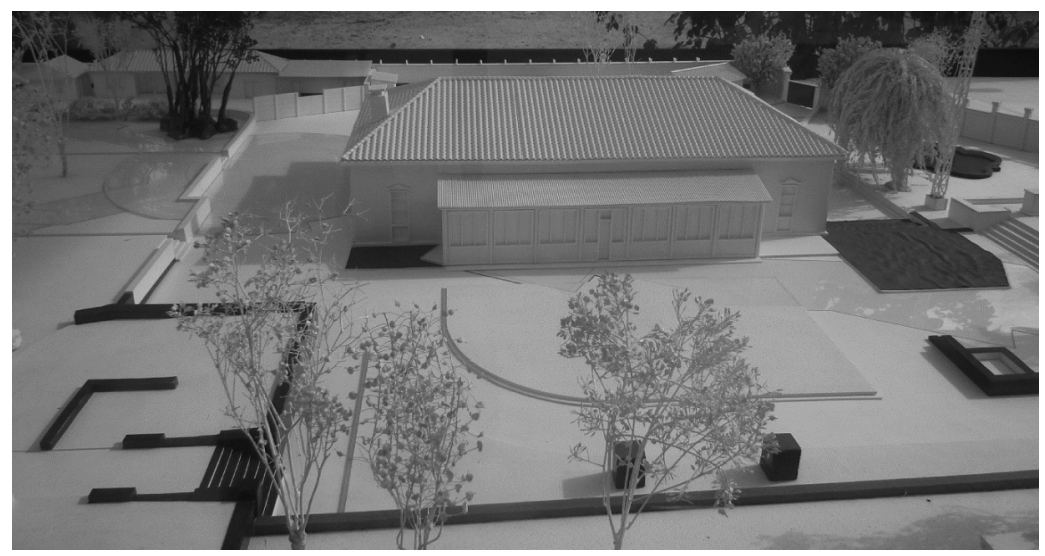

Photo: Fernando Rojas Corral (C) 2015 (printed with permission).

\section{Biopolitics ANd HOMO SACER IN Villa Grimaldi}

The purpose of this section is to apply the previous theoretical framework in the case study of Villa Grimaldi from 1974 to 1977, i.e. the years in which the place was used as the main clandestine torture center of DINA. Villa Grimaldi was managed and conditioned as a concentration and torture camp during the state of constitutional exception established by General Pinochet after the coup in Chile. In my opinion, the notions of biopolitics and homo sacer could be applied to explain what happened in Villa Grimaldi, but there are some additional considerations to take into account.

People were detained or kidnapped from their houses, workplaces, universities or even public spaces by secret police agents (GÓMEZ-BARRIS, 2009, p. 45), who blindfolded them while they were transported in cars or Chevrolet tracks without license plates until arriving to Villa Grimaldi. Once the metal door of the entrance was passed, the agents took the detainees down from the vehicle and, 'welcomed' them by hitting and kicking them all over their bodies. This 'ritual of passage' marked the transit from individual with rights to disappeared detainee or prisoner of DINA. Then, prisoners were taken to be interrogated over and over in the torture room. In this room the detainees were seated and tied, always blindfolded. If the agents did not obtain the information sought, then in most of the cases they undressed them and, tied them to the parrilla (metal bed or grill) and electrocute their bodies during the interrogation. The detainees received electric discharges in different parts of their bodies and, especially in the head, anus, genitals, etc., all of which caused painful burns (DURÁN, 2008, p. 172). In occasions, the electric shocks caused the 
loss of the sphincter control, what made prisoners defecate and, some of the perpetrators forced them to eat their own excrements. ${ }^{18}$ As María Eugenia Rojas explains,

[In the interrogation room] the detainee is insulted and hit; if he/she does not respond is undressed and placed on the grill, tied and gagged. It is frequent that a radio is played up loud to suffocate the screams of the victim. The use of physical and psychological torture, can last for several days; this depends on the attitude assumed by the detainee and the urgency with which the agents require the wanted information (ROJAS, 1988, p. 50-51).

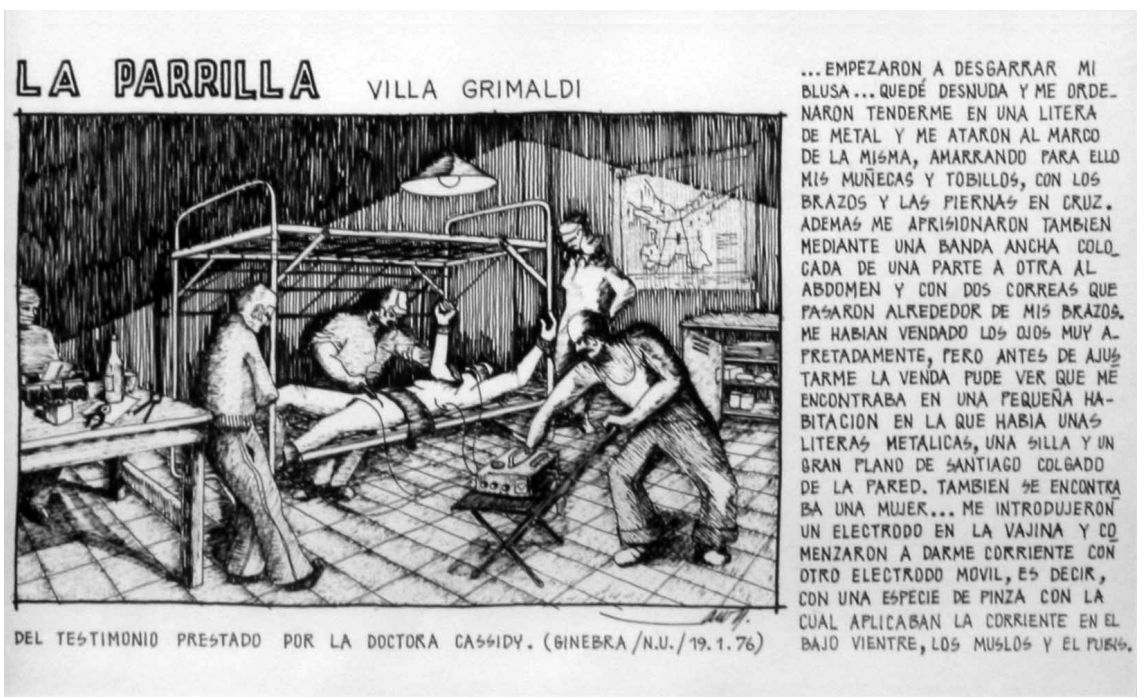

Drawn by prisoner Miguel Lawner (1976). Source: Lawner, 2003. The original drawing is part of a collection on exhibition at the Museo de la Memoria y los Derechos Humanos (reference code: CL MMDH 00000014-000005-000053).

In general women were sexually humiliated, abused or assaulted. When forcing them to get undressed the agents looked at their bodies and, when they tied them to the grill they opened their legs to see their genitals. Male agents also told obscenities to female prisoners and touched their breasts or other parts of their bodies, even introduced objects in their vaginas. Many testimonies that have been published by women survivors of tortures contain references to violations and sexual abuses but, 
also to the serious after-effects of such acts (ROJAS, H., 2012, p. 343-405). Do not think that only the women were object of sexual humiliations in Villa Grimaldi because, men also had to suffer sexual taunts. For example, Ángela Jeria General Alberto Bachelet's widow, who died in prison in 1974 and, mother of Michelle Bachelet, President of Chile (2006-2010 and 2014-) and former Executive Director of the United Nations Entity for Gender Equality and the Empowerment of Women (UN Women, 2010-2013) has mentioned the following aberration that she observed through the cell where she was kept:

They took a group of young men in very bad conditions there, some of them wounded. They forced them to put their pants down and, to align in front of others. To those that were behind, they ordered them to put a finger in the anus of the person in front while masturbated. All this among the laughter and gibes of those who watched over them (GUZMÁN; ROJAS, 2005, p. 129; VILLAGRÁN, 2002, p. 101-102). ${ }^{19}$

The interrogations had the purpose of obtaining information about the leaders of the parties of Unidad Popular and MIR. For example, agents asked for names, meeting places, hiding places, contacts, collaborators, networks, etc. The declarations of the detainees were used as records to pursue and arrest other people and so, to ruin any possible resistance against Pinochet's military government. For example, Manuel Donoso lost consciousness as result of the electricity in his body. On the following day, agents took him out again for further interrogation and, they asked for names of members of the PC and their meeting places. As he did not provide any information, they hit him with fists, kicks and gun butts all over his body; they put him against a wall and made the machine guns sound (DONOSO, 2008, p. 165). There is no doubt that mock shootings are a psychological torture technique because, "right after it, one did not know if he was dead or alive" (HERMOSILLA, 2008, p. 272). In spite of the fear produced by mock shootings, there were other worse tortures. For example, agents brought other people into the camp including family members and friends and placed them on other grill and torture them, so they could listen the screams and because of that obtain the sought information. The collection of survivors' testimonies One Hundred Voices Break the Silence (2008, in Spanish) includes the heartbreaking stories of Hernán Villegas and his 15 year-old son. As the minor could not bear the pain of the tortures any longer, he begged his father to tell the agents what they wanted. In those stories written 30 years after the arrests, it is possible to see the horror of that time and the long-terms effects in their lives.

Father - We arrived to Villa Grimaldi and they put my son on one grill and me on another grill. They began to throw water on us and my poor son 
told me: 'Daddy, daddy, tell them what you know so they won't kill me...Daddy, daddy, save me, don't let them kill me.' He was 14 years old... In that time he was studying but, he could not go on with his studies because they screwed him (VILLEGAS, H., 2008, p. 577).

Son - They tortured me a lot: electricity, burns, blows in my whole body but, mainly in my testicles and head...I begged my dad to answer everything they asked so that they didn't make me suffer anymore (VILLEGAS, J., 2008, p. 575).

It is appropriate to mention that during the interrogations not only agents of DINA participated but, rather in occasions there were also medical doctors that collaborated in the tasks of reviving those who were tortured or to indicate the moment in which the interrogators should stop otherwise, the prisoner would die. Once the tortures finished, the detainees were taken to small cells where they had to remain the rest of the time. For example, the denominated Casas Chile (Chile Houses) were a 0.7 square meters wooden box of 2 meters of height, with a very small opening at the bottom of the door for air (LEYTON, 2008, p. 301). Some years ago, a survivor explained to me that to rest in a place like that you had to learn how to sleep standing up and leaning on the walls of the box. Héctor González, who was detained in Villa Grimaldi for six months, has explained that the reason of placing the prisoners in Casas Chile was to isolate and torture them in totally closed cells: "It was exasperating to be inside there, without light, with very little air and very hot, standing up or sat down on the floor with the legs bent because, it was not possible to stretch them...how many days and nights we spent there because, it was the place where you lost the notion of time more quickly" (LEYTON, 2008, p. 300).

They could also be taken to Casas CORVI (CORVI Houses) which were a one squared meter box, but they had to share it with other detainees so they had to organize and cooperate together to be able to move. In those places, they always had to remain blindfolded and chained. Luis Leyton has narrated that they put four detainees in each of those cells, having to take turns to be able to rest (LEYTON, 2008 , p. 301). As they could not take a bath, the smell was unbearable and same as the prisoners in Casas Chile, they had a fixed schedule to go to the only bathroom and for just a few minutes each day. Many of the survivors have referred to the deep experiences of solidarity and affection that lived in Villa Grimaldi. For example, "when one was taken out to be tortured the others told you 'strength comrade, we are with you'. These expressions rebounded in the soul and in the conscience of each one of us like a warm medicine that invigorated the whole body" (MOYA, 2008 , p. 353). For example, a couple was arrested and taken to Villa Grimaldi and 
as both knew they were in the same detention center but could not see each other, she sang to him loud not only to encourage only him but also all the other prisoners.

Claudio resisted and survived the torture sessions thanks to the solidarity of the rest of the detainees and, to Gabriela's chant, his partner, who was also detained in some place of the enclosure. She, with her melodious voice offered us songs that the wind took charge of diffusing. Her singing was listened all over the camp, it went through the walls of the cells and, silenced the threats of the torturers... until arriving to the lover's ears that received the message and, saw his energy to resist multiply (MOYA, 2008, p. 358-359).

\section{figure 3 - Cell FOR PRisoners at Villa Grimaldi}

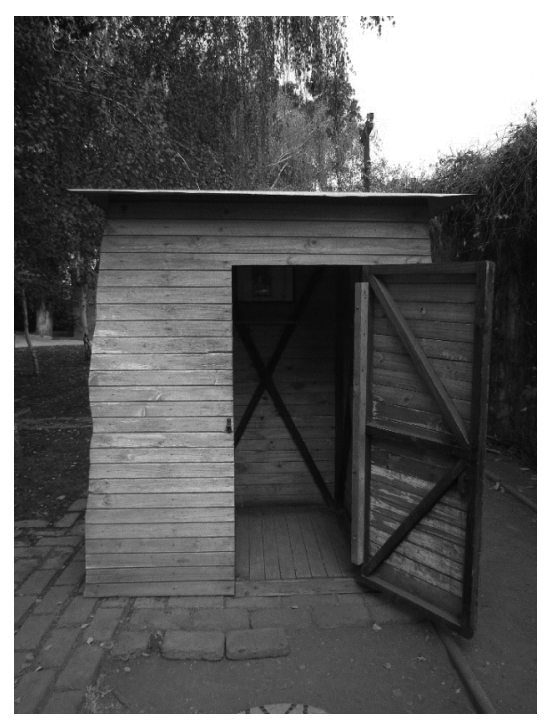

Photo: Fernando Rojas Corral (C) 2015 (printed with permission).

The most feared place was the tower, a six meter high construction located at the end of the enclosure and besides the swimming pool of the main house. The tower had a double function of surveillance and prison. The interior of the tower had a stairway with the shape of a snail from where it was possible to access a group of ten small wooden cells of 0.7 square meters. To enter such cells, it was necessary to cross a small door so, the detainees had to kneel down and go on all fours (as animals). In 
the tower, there was also a small room specially equipped to interrogate and torture the prisoners. It is known that very few were able to survive the tower. In fact, those who were sent to that place were usually because DINA had decided to end their lives. The prisoners that were in the tower remember that they listened how during the summer nights, men and women that worked as agents of DINA in that place, dove and enjoyed the pool. The contrast could not be more shuddering: on the one hand, agents that made parties in a pool located beside the cells of the prisoners whose deaths had already been resolved; while on the other hand, prisoners had to listen to the laughs and drunken agents' orgies in a pool that had been used for torturing prisoners with the 'submarine' technique during the day. ${ }^{20}$

figure 4 - The Tower at Villa Grimaldi

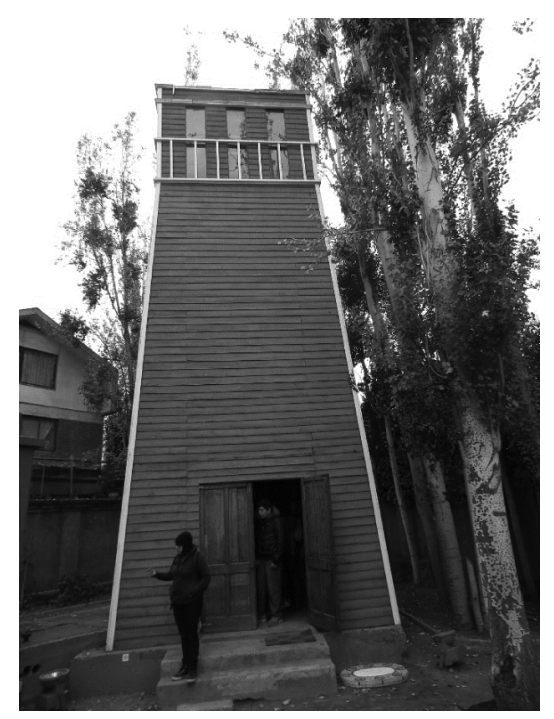

Photo: Fernando Rojas Corral C 2015 (printed with permission).

Once the death of the prisoners was decided, they were taken to Tobalaba aerodrome or Peldehue base. Prisoners were tied to rails and irons, then they were put into helicopters and finally thrown into the sea. Some of those rails were found by Judge Juan Guzmán, during the investigations of the human rights cases he conducted at the Court of Appeals of Santiago between 1998 and 2005, including the Pinochet Case. Since 2007, the rails are part of a memorial in Villa Grimaldi. On the other hand, if the leaders of DINA decided to set the prisoners free, they were usually 
forced to sign documents in which they declared being well treated by the police (HERMOSILLA, 2008, p. 272). And then, they were taken to Cuatro Álamos or Tres Álamos concentration camps and detention centers. In those enclosures they would remain for several months, until DINA took a final decision or changed its mind. In Tres Álamos the conditions were better than in Cuatro Álamos; the detainees could be visited shortly by their relatives and were able to receive food and clothes. The information mentioned above, has been confirmed by many survivors who have said that Tres Álamos allowed victims to recover while, in Cuatro Álamos "the detainees were in wait and they could be sent to Villa Grimaldi” (VIDAL, 2008, p. 567-568).

As it can be seen, the proceedings used by DINA agents in Villa Grimaldi were similar to any assembly line (TAYLOR, $1967[1911])^{21}$ : (1) the person was arrested and kidnapped; (2) when entering the place, the person became a prisoner and agents gave him a 'welcome' reception; (3) then the interrogations and tortures began; (4) the prisoner was located in small cells so, he/she could not rest and recover; (5) if agents considered it necessary, the prisoner was subjected to interrogations, humiliations and tortures again and again; (6) finally, the decision regarding the prisoner's life was taken by differing among those who were taken to the tower or other detention centers. Just as José Moya has explained it; to be detained in Villa Grimaldi was like "to be sat in a lobby waiting for your turn to meet with death... Both, detainees and death, we were caught by a group of wicked armed ones that day and night inside these haunts delighted with the physical pain they inflicted to men and women" (MOYA, 2008, p. 355). In substance, individuals were reified, they were not longer considered as people and, they simply became a number and an object to hit and torture with total freedom and impunity. The life conditions were inhuman, food was precarious, detention places were boxes in which not even animals deserve to be in, prisoners were isolated and blindfolded the whole time, suffering tortures and listening how other prisoners were tortured. In sum, the power of the state on the prisoners' bodies was absolute. To be in Villa Grimaldi was probably one of the nearest experiences to spend a season in hell.

figure 5 - Villa Grimaldi Assembly Line

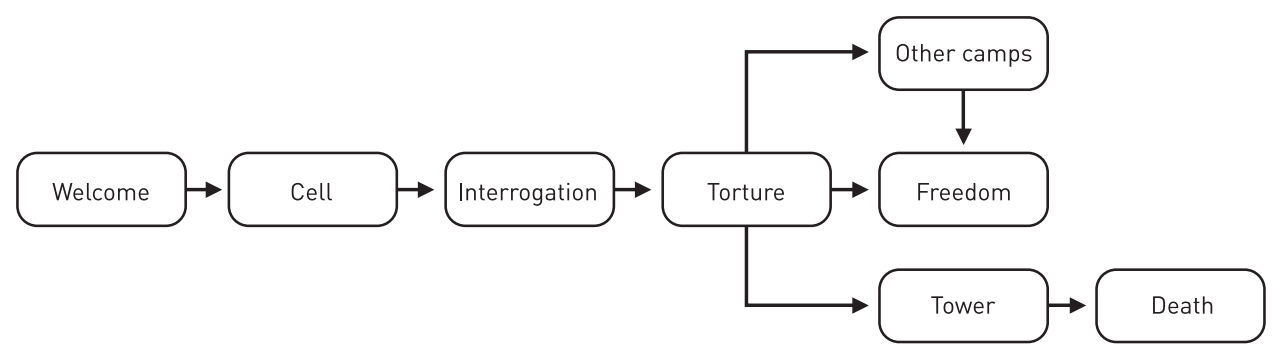


In that context of abuse and total control by the state, we have to add the nonexistence of appropriate legal mechanisms to defend the prisoners. Those who were arrested by DINA and taken to Villa Grimaldi were no longer subjects of law. The state and the secret police penetrated in the biological life of the detainees with impunity. The clandestine detention camp is the ultimate expression and paroxysm of biopolitics and disciplinary mechanisms. Just as the figure of the homo sacer in the Archaic Roman law, these people were outside the law and the act of killing them was not considered a crime. DINA agents did not have to respond before anybody for the death of a prisoner in Villa Grimaldi. Everything that happened in that place was a secret and denied by DINA and, in case of internal questionings, the 'national security' and 'internal war' arguments prevailed. Detained people were not entitled to anything; they could not make a phone call or communicate with their relatives, much less receive visits or hire the services of a lawyer. When their relatives looked for them and formulated habeas corpus or other legal petitions, the judges of the Court of Appeals of Santiago, as well as the vast majority of the judiciary, only conformed transmitting the answers they received from the Ministry of Interior: the individuals have not been arrested nor they are in the lists of prisoners. For example, between September 1973 and September 1983 the Committee of Cooperation for the Peace and the Vicarage of Solidarity gave assistance on the preparation or presentation of 5,400 habeas corpus before the Court of Appeals of Santiago, which together accepted ten habeas corpus and only in four cases the freedom of the prisoner was achieved (ROJAS, 1988, p. 11). In consequence, the executive branch and the judiciary did not do anything to impede the violations of human rights made by the agents of DINA or other state officials.

Once the prisoner was released and the fear of being kidnapped or tortured once again vanished e.g. exiles abroad, end of the dictatorship in 1990, etc. he/she is no longer a homo sacer and (supposedly) recovers the condition of subject of law. The experience of being tortured in camps like Villa Grimaldi makes it impossible to assume that the victim will be the same as before the arrest: it is now a victim, a survivor, and a witness. The recovery of fundamental rights does not mean that the survivors' nightmare has ended. In many cases the pain continues for diverse reasons, such as: lack of understanding and empathy of the rest of the society; having to leave the country and start a new life abroad; prejudices, stigmatization, and discrimination; serious physical and psychological after-effects; destruction of dreams, ideals, and life's projects; insufficient state reparation to compensate the damage; loss of relatives and friends; impunity of perpetrators, etc. (ROJAS, H., 2012, p. 353-405).

If from an ethical point of view in any process the human condition never fades, it is perfectly possible to make distinctions according to the moment in which the person is. Because of that, it is interesting the notion that Agamben uses to refer to someone whom is detained in a camp, at the mercy of the will of the guards. But the concept 
of homo sacer loses its significance and opportunity once the prisoner is released and recovers the condition of subject of law. Maybe a way to talk about the survivor that leaves the camp, returns to the polis and, faces some of the difficulties previously mentioned, could be the expression superstes tormentorum (torture survivor). In other words, I believe a different concept to homo sacer is needed in order to allude to the person that has been detained and tortured in clandestine centers, without judicial guarantees, during a de facto regime or state of constitutional exception and, that later is liberated and then has to deal with a set of unexpected problems that affect his/her life and development as person, amplifying or prolonging the pain.

\section{CONCLUSIONS}

This article has shown how during the dictatorship of General Pinochet in Chile nonhuman disciplinary and control devices were applied in concentration camps like Villa Grimaldi. These techniques became more 'efficient' after DINA agents learned and accumulated experience in the commission of acts of torture against political prisoners. Villa Grimaldi should not only be seen as a matter of control and 'normalization' of nearly 5,000 individuals in a 'disciplinary' society under the rule of the armed forces. In addition, the Chilean state used the camps to seek information through extreme repressive measures, threatened the population and prevented any opposition of the members of the left-wing parties to the exercise of the armed forces' political and military powers. Pinochet's dictatorship killed and tortured people with ideological purposes, for this he invoked not only his sovereign power to kill his opponents but also his regulatory power over the life of the population. Consequently, Villa Grimaldi can be interpreted as an example of modern techniques of individual control and discipline and of an abusive exercise of state's biopolitics, as Foucault has warned us in his mature writings. One critic presented in this occasion to Foucault's theory of power has to do with the emphasis he makes in race and racism as the ultimate foundation of biopolitics. The revision of the Chilean experience allows me to conclude that it is not possible to ignore or exclude political ideologies as an important variable in the exercise of biopower in modern societies.

Also, it has been shown how persons who were kidnapped and placed in secret concentration camps like Villa Grimaldi lost their condition of legal subjects. The possibilities they had to defend themselves were limited: the military government denied most of the arrests; the courts denied the habeas corpus presented by the relatives and lawyers of the disappeared detainees; the self-amnesty Decree Law of 1978 impeded for years the investigation of crimes committed during the first five years of the dictatorship, etc. We have seen how prisoners in camps like Villa Grimaldi were terribly humiliated, beaten, threaten, reified by sadist secret police agents and members of the armed forces. The survivors' testimonies are heartbreaking, the nonhuman 
conditions of life in the camps and the horror of systematic torture sessions exceed the imaginable. In Villa Grimaldi, prisoners were put in an assembly line that started with the welcoming reception (ritual of passage) and in occasions ended with death, passing by the grill, hangings, threats, submarine, rapes, the tower, and other control devices. In that sense, the expression homo sacer appropriated by Agamben from the archaic Roman law is a useful figure to understand the complex legal condition of the prisoners tortured in the camps. For the agents of DINA the death of a prisoner was irrelevant and did not imply the commission of a homicide. Nevertheless, it has been explained that the notion of homo sacer does not make sense to allude to the situation of the 'victim-survivor-witness' after the act of liberation. Who survives the nightmare of the camp has to face several difficulties and, it is not reasonable to pretend that the human condition and life of the survivor will be the same as it was before the arrest. I argued that is preferable to use another expression that better reflects the life conditions of the victim-survivor-witness that comes back to the polis and restarts a new life. The notion presented here for further discussion is superstes tormentorum (torture survivor), which might contribute to the understanding about the complexities in the life of a homo sacer that recovers freedom and faces unpredicted and even more painful circumstances than torture because the trauma does not end with the mere act of release.

\section{NOTES}

* I would like to thank the contributions made by Simón Escoffier, María Angélica Garrido, Alejandro Gómez, Milena Grass, Evelyn Hevia, Yanina Hinrichsen, Ronald Jennings, Elizabeth Lira, Pedro Matta, Tim Murphy, María Antonieta Nestor, Leigh Payne, Mariana Penna, and Robert Wardrop. All errors are mine.

1 Agamben (1998 [1995]; 2010 [1996]; 2010 [1999]; 2010 [2003]). All translations are mine.

2 Foucault (1987 [1975]; 1978 [1976]; 2003 [1997]; 2010 [2004]). All translations are mine.

3 For more information, see <http://www.villagrimaldi.cl $>$.

4 For more information, see <http://www.museodelamemoria.cl>.

5 For more information, see $<$ http://www.vicariadelasolidaridad.cl $>$.

6 For more information, see <http://www.comisionvalech.gov.cl>. The Valech Report II was presented to President Sebastián Piñera on August $18^{\text {th }} 2011$, adding 9,830 new cases to the list of 28,459 victims of torture and political imprisonment identified in the Valech Report. See Diario E1 Mercurio, August $19^{\text {th }} 2011$, C2. 
7 For example, see Buchenwald and Mittelbau-Dora Memorials Foundation, The Engineers of the "Final Solution”. Topf \& Sons - Builders of the Auschwitz Ovens (Weimer: 2005).

8 Modern constitutionalism has accepted the inclusion of state of exception's norms in constitutions. For example, Hitler invoked Article 48, 2, of the Weimar Constitution to rule between 1933 and 1945. See Kennedy (2004).

9 As Pompeius Festus explains, "The sacred man is the one whom the people have judges on account of a crime. It is not permitted to sacrifice this man, yet he who kills him will not be condemned for homicide; in the first tribunitian law, in fact, it is noted that "if someone kills the one who is sacred according to the plebiscite, it will not be considered homicide." This is why it is customary for a bad or impure man to be called sacred" (quoted by G. AGAMBEN, 1998 [1995], p. 71).

10 As Katia Genel points out, "The life of Homo sacer, an obscure figure of archaic Roman law which can be killed without committing homicide but which cannot be sacrificed in any ritual form, is a life destined to die with complete impunity" (GENEL, 2006, p. 51).

11 According to Agamben, "The Foucaldian thesis will ... have to be corrected or, at least, completed, in the sense that what characterizes modern politics is not so much the inclusion of zoe in the polis-which is, in itself, absolutely ancient - nor simply the fact that life as such becomes a principal object of the protections and calculations of State power" (AGAMBEN, 1998 [1995], p. 9).

12 Decree Law n. 521, 14 June de 1974, was partially published in the official gazette and some of its norms were only known by a limited number of persons.

13 Hinchey Report, 'Relationship with Contreras,' available at <http://foia.state.gov/reports/ hincheyreport.asp>.

14 For example, in 1974 former Commander in Chief of the Army Carlos Prats and his wife were killed in Buenos Aires. In 1975, former Vice President Bernardo Leighton and his wife were seriously injured. In 1976, former Minister Orlando Letelier and his secretary were killed in Washington, D.C.

15 Decree Law n. 1.878, August $13^{\text {th }}, 1977$.

16 "Except for a short period as a restaurant, Villa Grimaldi was a place of imitation, where the elite displayed its economic difference and indifference to Chile's popular classes through a grandeur and opulence it could not sustain.” (GÓMEZ-BARRIS, 2009, p. 44-5)

17 Information based in Corporación Parque por la PazVilla Grimaldi, ExposiciónVilla Grimaldi. Presente, pasado y futuro (Santiago: privately printed, s.d.); Corporación Parque por la Paz Villa Grimaldi Website, <http://www.villagrimaldi.cl>; N. Fuentes et al. (s.d.), 9'20", available at <http://www.youtube.com/watch?v=xaBgoBAmCbU>; M. Gómez-Barris2009, p. 44-5; P. Matta (2000); S. Milla et al., (2007), 10'27", available at <http://www.youtube.com/watch?v=vE8Ve8-xPwc>; M.E. Rojas (1988), p. 50-4; H. Vásquez (coord.), (2010, p. 47-8), available at <http://www.londres38.cl/1937/articles90933_recurso_1.pdf>; Resolution n. 3.575, Corporación de Mejoramiento Urbano; 1974; Decree n. 264, Ministery of Education, 27 April 2004; Rettig Report (1) 55 and (2) 720; Ministerio de la Vivienda y Urbanismo, Memoria de la ciudad (2009, p. 44).

18 P. Matta, 'Ante el suicidio de mi torturador', Revista Puro Chile, 30 January 2005, available at <http://www.paxsocial.com.ar/ante\%20el\%20suicidio.htm>.

19 In 2000, Mrs. Jeria recognized in the news the voice of the person that tortured her in Villa Grimaldi and, later noticed that the perpetrator was one of her neighbors.

20 The wet submarine consists in introducing the head of the prisoner in a container with liquid, causing temporal asphyxia.

21 I owe this comment to Pedro Matta. For a more detailed description of the torture process in Villa Grimaldi, see G. Salazar (2013). 


\section{REFERENCES}

Books, articles and documents

AGAmBEN, G. Homo Sacer. Sovereign Power and Bare Life. Stanford: Stanford University Press, 1998 [1995].

Medios sin fin. Notas sobre la política. Valencia: Pre-Textos, 2010 [1996].

Means Without End: Notes on Politics. Minneapolis: University of Minnesota Press, 2000.

Lo que queda de Auschwitz. El archivo y el testigo. Homo Sacer III. Valencia: Pre-Textos, 2010 [1999].

Estado de Excepción. Homo Sacer II, 1. Valencia: Pre-Textos, 2010 [2003].

BECKER, N. Una mujer en Villa Grimaldi. Santiago, Pehuén, 2011.

BENTHAM, J. The Panopticon Writings. London: Verso, 1995 [1791].

CASTRO, E. Giorgio Agamben. Una arqueología de la potencia. Buenos Aires: UNSAM EDITA, 2008), esp. Ch. 2

'Soberanía y Excepción', p. 49-85.

COMISIÓN NACIONAL DE VERDAD Y RECONCILIACIÓN, Informe Final. Rettig Report). Santiago:

Gobierno de Chile, 1991.

CORPORACIÓN Parque por la Paz Villa Grimaldi, Exposición Villa Grimaldi. Presente, pasado y futuro. Santiago: privately printed, s.d.), available at <http://www.villagrimaldi.cl/images/stories/docs/ed_revista_villa_ grimaldi.pdf?ml $=4 \& \mathrm{mlt}=$ villa_grimaldi $\&$ tmpl $=>$.

DONOSO, M. Un testigo de la historia represiva de Chile. In: KUNTSMAN, W.; TORRES, W. \& V. (eds.).

Cien voces rompen el silencio. Testimonios de ex presos políticos de la dictadura militar en Chile (1973-1990). Santiago:

Ediciones de la Dirección de Bibliotecas, Archivos y Museos, 2008, p. 163-167.

DURÁN, F. Lo que no se debe olvidar. In: KUNTSMAN, W.; TORRES, W. \& V. (eds.). Cien voces rompen el

silencio. Testimonios de ex presos políticos de la dictadura militar en Chile (1973-1990). Santiago: Ediciones de la

Dirección de Bibliotecas, Archivos y Museos, 2008, p. 171-173.

DURANTAYE, L. de la. Giorgio Agamben. A Critical Introduction. Stanford, CA: Stanford University Press, 2009.

ENSALACO, M. Chile bajo Pinochet. La recuperación de la verdad. Madrid: Alianza Editorial, 2002.

FOUCAULT, M. Vigilar y castigar. Nacimiento de la prisión. México D.F.: Siglo XXI, 1987 [1975].

Historia de la sexualidad. México, DF: Siglo XXI, 1978 [1976]. Vol. 1, La Voluntad de Saber.

Society must be defended. Lectures at the Collège de France 1975-1976. London: Penguin, 2003 [1997].

Nacimiento de la Biopolítica. Curso en el Collège de France 1978-1979. Buenos Aires: Fondo de

Cultura Económica, 2010 [2004].

FUENZALIDA, N. Cuartel Terranova. Análisis de la configuración espacial en relación a las estrategias de represión y control de detenidos y torturados. La zaranda de ideas, v. 7, n. 1, Jan./ June 2011.

GENEL, K. The Question of Biopower: Foucault and Agamben. Rethinking Marxism: A Journal of Economics, Culture \& Society, 18(1), 2006, p. 43-62.

GÓMEZ-BARRIS, M. Where Memory Dwells. Culture and StateViolence in Chile. Berkeley: University of California Press, 2009.

GUZMÁN R.; ROJAS, G. Bachelet. La Hija del Tigre. Santiago: RIL Editores, 2005.

HEFFES, O. D. Foucault y Agamben o las diferentes formas de poner en juego la vida. Revista Aulas, 3. Dec. 2006 - Mar. 2007, p. 1-22.

HERMOSILlA, M. Mujer y tortura. In: KUNTSMAN, W.; TORRES, W. \& V. (eds.). Cien voces rompen el silencio. Testimonios de ex presos políticos de la dictadura militar en Chile (1973-1990). Santiago: Ediciones de la Dirección de Bibliotecas, Archivos y Museos, 2008, p. 269-272.

HINCHEY REPORT, Relationship with Contreras. Available at <http://foia.state.gov/reports/hincheyreport.asp>. KENNEDY, E. Constitutional failure. Carl Schmitt in Weimar. Durham, NC: Duke University Press, 2004. LAWNER, M. Isla Dawson, Ritoque, Tres Álamos...: La vida a pesar de todo. Santiago: Lom Ediciones, 2003. LEYTON, L. Yo también estuve en la Villa Grimaldi. In: KUNTSMAN, W.; TORRES, W. \& V. (eds.). Cien voces rompen el silencio. Testimonios de ex presos políticos de la dictadura militar en Chile (1973-1990). Santiago: Ediciones de la Dirección de Bibliotecas, Archivos y Museos, 2008, p. 299-302.

MATTA, P. Villa Grimaldi, Santiago de Chile. A Visitor's Guide. Santiago: privately printed, 2000.

Ante el suicidio de mi torturador. Revista Puro Chile, 30 January 2005. Available at

<http://www.paxsocial.com.ar/ante\%20el\%20suicidio.htm>.

MINISTERIO DE VIVIENDA Y URBANISMO, Memoria de la ciudad. Santiago: Gobierno de Chile, 2009.

MOYA, J. Con la venda sobre los ojos. In: KUNTSMAN, W.; TORRES, W. \& V. (eds.). Cien voces rompen el silencio. Testimonios de ex presos políticos de la dictadura militar en Chile (1973-1990). Santiago: Ediciones de la Dirección de Bibliotecas, Archivos y Museos, 2008, p. 353-361.

POLICZER, P. The Rise and Fall of Repression in Chile. Notre Dame, IN: University of Notre Dame Press, 2009. ROJAS, H. 'Torture in Chile. 1973-1990): Analysis of One Hundred Survivors' Testimonies'. California Western 
International Law Journal, v. 42, n. 2, Spring 2012, p. 353-405.

ROJAS, M. E. La represión politica en Chile. Los hechos. Madrid: IEPALA, 1988.

SALAZAR, G. Villa Grimaldi. Cuartel Terranova. Historia, testimonio reflexión. Santiago: Lom, 2013.

SCHMITT, C. Political Theory. Four Chapters on the Concept of Sovereignty. Cambridge MA: The MIT Press. 1965 [1922].

TOLEDO et al., M.I. Visita a un lugar de memoria. Guía para el trabajo en derechos humanos. Santiago: Lom

Ediciones, 2009.

VÁSQUEZ, F. De la microfísica del poder a la gubernamentalidad neoliberal. Nota sobre la actualidad filosófica-política de Michel Foucault. Contrahistorias. La otra mirada de Clío, 12. May - Aug. 2009, p. 71-92.

VÁSQUEZ H. (ed.). Una luz sobre la sombra. Detenidos desaparecidos y asesinados de la Pontificia Universidad Católica de Chile. Santiago: 2010. Available at <http://www.londres38.cl/1937/articles-90933_recurso_1.pdf>.

VIDAL, H. Todavía me siento joven y con ganas de trabajar por una sociedad mejor. In: KUNTSMAN, W.;

TORRES, W. \& V. (eds.). Cien voces rompen el silencio. Testimonios de ex presos políticos de la dictadura militar en Chile (1973-1990). Santiago: Ediciones de la Dirección de Bibliotecas, Archivos y Museos, 2008, p. 565-571.

VILLAGRÁN, F. Disparen a la bandada. Una crónica secreta de la FACH. Santiago: Planeta 2002.

VILLEGAS, H. Aún no sé dónde estaban las armas. In: KUNTSMAN, W.; TORRES, W. \& V. (eds.). Cien voces rompen el silencio. Testimonios de ex presos políticos de la dictadura militar en Chile (1973-1990). Santiago: Ediciones de la Dirección de Bibliotecas, Archivos y Museos, 2008, p. 577-578.

VILLEGAS, J. Nunca supe por qué me torturaron. In: KUNTSMAN, W.; TORRES, W. \& V. (eds.). Cien voces rompen el silencio. Testimonios de ex presos políticos de la dictadura militar en Chile (1973-1990). Santiago: Ediciones de la Dirección de Bibliotecas, Archivos y Museos, 2008, p. 575-576.

\section{Audiovisual and oral archives}

FUENTES N. et al. Historia de la Ex Villa Grimaldi. Santiago: Universidad Metropolitana de Ciencias de la Educación, s.d.), 9'20". Available at <http://www.youtube. com/watch?v=xaBgoBAmCbU>.

MATTA, P. Remembrance and Hope. Conference at Missouri State University, 2008). Available at $<$ http://www.youtube.com/watch?v=e_5fgBpd4lg $>$.

MILLA S. et al. 'Villa Grimaldi, Espacio de Memorias'. Santiago: Universidad de Santiago \& Cosmovisión Producciones, 2007), 10’27”. Available at <http://www.youtube.com/watch?v $={ }_{v} E 8 V e 8-x P w c>$.

PARQUE POR LA PAZ VILLA GRIMALDI, Archivo Oral. Santiago: 2011.

\section{Websites}

Centro de Derechos Humanos - Universidad de Chile, <http://www.cdh.uchile.cl>.

Corporación Parque por la Paz Villa Grimaldi, <http://www.villagrimaldi.cl $>$.

Comisión Nacional sobre Tortura y Prisión Política (Valech Commission), <http://www.comisionvalech.gov.cl $>$. Fundación Centro de Documentación y Archivo Vicaría de la Solidaridad, <http://vicariadelasolidaridad.cl $>$. Memoria Viva, <http://www.memoriaviva.com>.

Museo de la Memoria y los Derechos Humanos, <http://www.museodelamemoria.cl>.

Hugo Rojas Corral Santiago - Chile
hurojasquahurtado.cl

Professor of Sociology of LAW (Alberto HuRTADo University School of LAW).

Doctoral Candidate in Sociology (University OF OXFord, Wolfson COLlege).

Master of Science in LaW, Anthropology, and Society (London School of Economics \& Political Science).

Master in Management and Public Policy (ADOLFO IBÁÑEZ UnIVERSITY). 